\title{
PERANCANGAN SISTEM INFORMASI ABSENSI KELAS BERBASIS QR CODE MENGGUNAKAN PHP \& MYSQL PADA KAMPUS POLINAS LP3I ALAUDDIN MAKASSAR
}

Nurhaedar

\begin{abstract}
Abstrak : Sistem Informasi Absisnsi kelas di kampus POLINAS LP3I Alauddin masih menggunakan sistem manual dalam proses mengabsen mahasiswa di mana ketika dosen mengabsen, harus memerlukan banyak waktu untuk menyebutkan nama mahasiswa satu persatu yang sebenarnya sebagian waktu tersebut dapat di gunakan untuk diskusi atau tanya jawab dan dapat di pungkiri adanya mahasiswa yang merubah absen tersebut di kemudian hari serta memerlukan banyak waktu bagi pihak akademik untuk mengitung jumlah kehadiran mahasiswa di setiap mata kuliah. Penelitian ini bertujuan untuk merancang sistem absensi berbasis QR Code untuk mengefisienkan waktu mengabsen dan menghitung data absensi serta meminimalisisr kecurangan mahsiswa dalam memanipulasi absen. Pengembangan sistem menggunakan metode waterfall, perancangan sistem menggunakan metode orientasi berbasis UML (Undifinied Modeling Language), penulisan program menggunakan bahasa pemrograman PHP, pembuatan database menggunakan PhpMyAdmin dan pengujian yang dilakukan terhadap sistem absensi berbasis QR Code ini menggunakan metode blackbox. Hasil penelitian ini mewujudkan sistem absensi berbasisQR Code ini dapat mengefisenkan waktu dalam kegiatan mengabsen dan mencegah terjadinya manipulasi absen serta dapat membantu pihak akademik mendata kehadiran mahasiswa dengan mudah dan efisien.
\end{abstract}

\section{Kata Kunci : Sistem informasi, Absensi kelas mahasiswa, QR Code}

Abstract : System Information of absence in Polinas is the high institution that harmonize between educational system with need of trade and industry area. In the campus of Polinas LP3I Alauddin, the lecturers checked their students' attendance manually. This process spent much time because the lecturers should call all students' name one by one. Whereas, the time will be more effective if used for discussion or questioning. Besides, there is possibility that the students can change the absence. This process also can spend more time for academic study in counting students' attendance in each lecturer. The objective of this study is to design attendance system based on QR Code to help the lecturers in checking their students' attendance, to prevent the students in changing their attendance, and to help academic study in counting the total attendance of students in each courses. This sistem will be built in using aids of UML design and engineering of waterfall software. The software that used in programming terminology is called PHP and MySql.This system can support 
in applying management system based on IT in campus of Polinas LP3I Alauddin of Makassar in checking attendance. This system is expected can make time more efficient in checking attendance and can prevent manipulation of absence. And also, it can help academic study in collecting data of students' attendance easily and more efficient.

Keywords : Information system, student class attendace, QR Code

\section{PENDAHULUAN}

Pemanfaatan teknologi informasi dalam kegiatan sehari hari sangatlah penting karena memiliki banyak manfaat untuk kehidupan di era digital seperti sekarang ini, dengan memanfaatkan kecanggihan teknologi informasi, kita bisa mengerjakan banyak hal dalam hitungan menit. Teknologi informasi benar-benar bisa membantu dalam melakukan pekerjaan dan menyelesaikannya lebih efektif dan efisien.

Saat ini pemanfaatan teknologi informasi sudah banyak di terapkan dalam kehidupan manusia baik dalam pemerintahan, industri, dunia medis dan pendidikan. Kebutuhan sistem informasi bukan lagi sebagai pelengkap, tapi merupakan sebuah kebutuhan dalam segala aspek. Salah satu pemanfaatan teknologi informasi dan komunikasi dalam dunia Pendidikan ialah aplikasi absensi menggunakan QR Code. Aplikasi absensi menggunakan QR Code merupakan salah satu aplikasi yang dapat di gunakan untuk mengabsen mahasiswa yang hadir dalam mata kuliah dengan menscan QR Code yang di berikan oleh dosen tanpa harus menyebutkan nama mahasiswa satu persatu yang dapat memakan banyak waktu dalam kegiatan mengabsen dan tanpa adanya manipulasi ataupun perubahan absen dari mahasiswa di kemudian hari dan lebih memudahkan pihak akademik untuk mendata kehadiran mahasiswa. banyaknya mahasiswa yang menitipkan absen ataupun mengubah isi absen tersebut yang akan menimbulkan banyak kecurangan yang terjadi karena telah memanipulasi absen agar tetap tercatat sebagai mahasiswa yang telah memenuhi standar kehadiran. Sementara itu, pada Kampus Polinas LP3I Alauddin Makassar masih menggunakan sistem manual dimana ketika dosen mengabsen, harus memerlukan banyak waktu untuk menyebutkan nama mahasiswa satu persatu yang sebenarnya sebagian waktu tersebut dapat di gunakan untuk diskusi atau tanya jawab dan dapat di pungkiri adanya mahasiswa yang merubah absen tersebut di kemudian hari serta memerlukan banyak waktu bagi pihak akademik untuk mengitung jumlah kehadiran mahasiswa di setiap mata kuliah. Maka kebutuhan akan suatu teknologi yang dapat mengelola data-data absensi mahasiswa dengan cepat dan akses dalam memperoleh sebuah informasi menuntut penulis untuk membangun aplikasi absensi yang dapat membantu mengefisienkan waktu dalam kegiatan mengabsen dan proses pendataan absensi mahasiswa Berdasarkan uraian diatas, maka dibutuhkan suatu terobosan baru Rancangan Sistem Informasi absensi mahasiswa dengan menggunakan teknologi QR Code. pada Kampus Polinas LP3I Alauddin Makassar.

\section{Tujuan Penelitian}

$\begin{array}{lcr}\text { 1. Merancang } & \text { Sistem } & \text { Informasi } \\ \text { absensi } & \text { mahasiswa } & \text { dengan } \\ \text { menggunakan teknologi } & \text { QR Code. }\end{array}$

(C) 2020 STIE TDN. All rights reserved 
pada Kampus Polinas LP3I Alauddin Makassar.

2. Merealisasikan rancangan Sistem Informasi absensi mahasiswa dengan menggunakan teknologi QR Code. pada Kampus Polinas LP3I Alauddin Makassar.

\section{Manfaat Penelitian}

Dengan adanya penelitian ini di harapakan dapat memberi manfaat baik itu diri sendiri maupun bagi pihak instansi. Ada pun manfaat yang bisa di dapatkan dari penelitian ini yaitu :

1. Dengan adanya system informasi dapat membantu akademik dalam melakukan proses pendataan absensi Mahasiswa secara cepat, mudah dan efisien.

2. Memudahkan para dosen mengabsen mahasiswa secara efiseinsi dan efektif

3. Mendisiplinkan mahasiswa terhadap kehadiran serta mencegah adanya manipulasi absen.

\section{TELAAH LITERATUR DAN PENGEMBAHAN HIPOTESIS}

Menurut Romney dan Steinbart (2015:3), sistem adalah suatu rangkaian yang terdiri dari dua atau lebih komponen yang saling berhubungan dan saling berinteraksi satu sama lain untuk mencapai tujuan dimana sistem biasa nya terbagi dalam sub system yang lebih kecil yang mendukung system yang lebih besar.(Gee, 2003)

Quick Response Code atau yang biasa disebut dengan QR Code merupakan sebuah barcode dua dimensi yang diperkenalkan oleh Perusahaan Jepang Denso Wave pada tahun 1994. Jenis barcode ini awalnya digunakan untuk pendataan inventaris produksi suku cadang kendaraan dan sekarang sudah digunakan dalam berbagai bidang layanan bisnis dan jasa untuk aktivitas marketing dan promosi. Pada dasarnya QR Code dikembangkan sebagai suatu kode yang memungkinkan isinya untuk dapat diterjemahkan dengan kecepatan tinggi. Menurut Law, C. \& So, S.menyatakan bahwa QR Code merupakan bentuk dua dimensi dari barcode. QR Code dikembangkan oleh Denso Wave yang digunakan untuk mendata sparepart kendaraan pada tahun 1994.

QR Code adalah image berupa matriks dua dimensi yang memiliki kemampuan untuk menyimpan data di dalamnya. QR Code merupakan evolusi dari kode batang (barcode). Barcode merupakan sebuah simbol penandaan objek nyata yang terbuat dari pola batang-batang berwarna hitam dan putih agar mudah untuk dikenali oleh komputer. Contoh sebuah QR Code dapat dilihat pada gambar (Nugraha \& Munir, 2011)

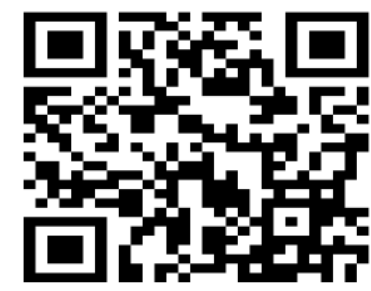

Gambar 2.1 Contoh QR Code

Metode Pengembangan Sistem

Tahapan Pengembangan Sistem Informasi Absensi

Metodologi system development life cyle (SDLC) / daur hidup pengembagan sistem. system development life cyle (SDLC) sendiri merupakan suatu tahapan - tahapan pekerjaan yang digunakan oleh anisis sistem untuk untuk membangun atau mengembangkan suatu sistem yang baru, melalui beberapa tahapan. SDLC sendiri dikenal sebagai metode pengembangan sistem yang berbentuk waterfall atau model air terjun yang 
umunya banyak di pakai atau digunakan pengembang dalam membangun suatu sistem informasi yang baru, karena model ini melaukan pendekatan yang sistematis terhadap perancangan system Dalam siklus SDLC, terdapap 6 tahapan yang sercara umum harus terpenuhi dalam perancangan sistem, tahapan-tahanpan antara lain:

1. Analisis system, yaitu membuat analisis aliran kerja manajemen yang sedang berjalan. Pada tahap ini Penulis melakukan penelitian pada kampus Polinas LP3I Alauddin Makassar untuk mengevaluasi masalah, menetapkan masalah, menentukan tujuan sistem.

2. Spesifikasi kebutuhan / analisis kebutuhan sistem, yaitu melakukan perincian tentang apa saja yang dibutuhkan dalam pengembangan sistem dan membuat perencanaan yang berkaitan dengan proyek sistem absensi berbasis QR Code dan kendala yang dialami pada sistem yang lama, kemudian membuat model logika dari pemecahan yang direkomendasikan dan menggunakan metode terstruktur.

3. Perancangan sistem, yaitu membuat desain aliran kerja manajemen dan desain pemrograman yang diperlukan untuk pengembangan sistem informasi. Perancangan ini menggunakan alat bantu mengunakan metode orientasi berbasis object/UML (Undifinied Modeling Language).

4. Penulisan program, yaitu tahap pengembangan sistem informasi dengan menulis program yang sudah dirancang dan menentukan bahasa pemrograman yang digunakan. Pada kesempatan kali ini peneliti memilih bahasa pemrograman PHP dalam penulisa program dan database
PhpMyAdmin dalam pembuatan database.

5. Pengujian sistem, yaitu melakukan pengujian terhadap sistem yang telah dibuat. Pengujian dilakukan dengan menggunakan metode pengujian blackbox.

6. Implementasi dan pemeliharaan sistem, yaitu menerapkan dan memelihara sistem yang dibuat.

\section{Desain Rancangan Rekayasa Perangkat Lunak Model UML Desain Use Case Diagram}

Use case diagram merupakan diagram yang menyajikan interaksi antara use case dan actor. Use case menggambarkan persyaratanpersyaratan yang harus di penuhi oleh sistem dari pandangan pemakai.

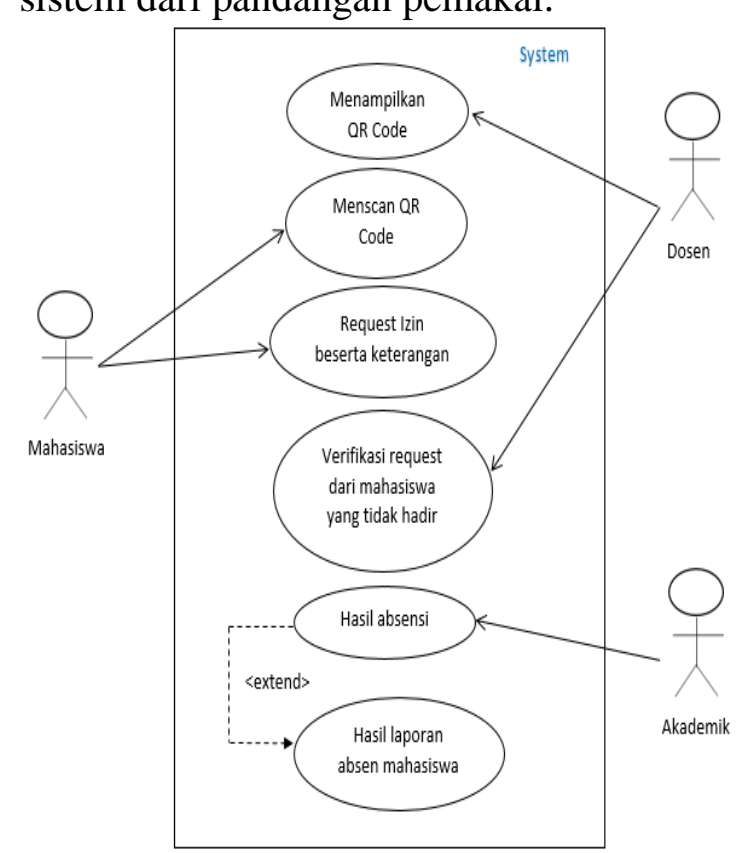

Gambar 3.1 Use Case Diagram

\section{Desain Class Diagram}

Class diagram menggambarkan struktur dan deskripsi class, package dan objek beserta hubungan satu sama lain. Dengan demikian dapat dipahami bahwa class diagram Menggambarkan struktur statis didalam sistem.. 


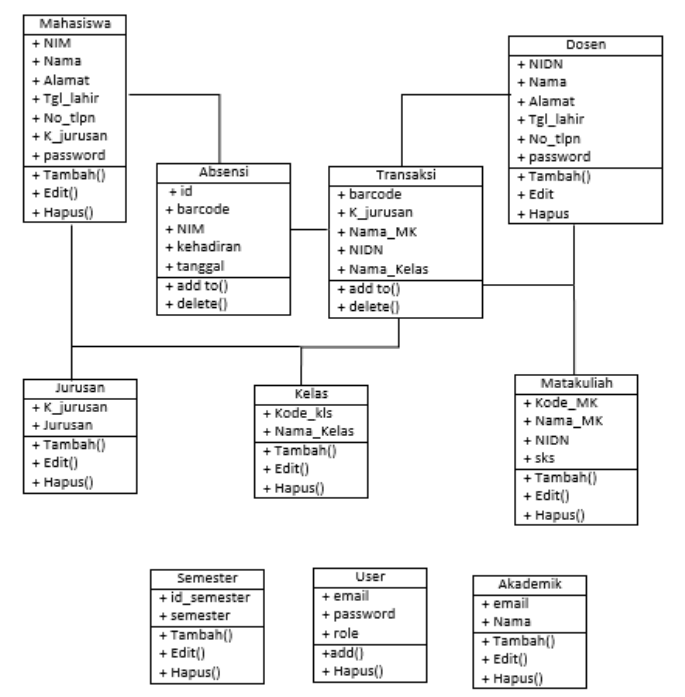

\section{Desain Squence Diagram}

Sequence diagram merupakan gambaran interaksi antara sejumlah object dalam urutan waktu. Kegunaannya untuk menunjukan rangkaain pesan yang dikirim antara object juga interaksi antara object yang
Gambar 3.2 Class Diagram Absensi

terjadi pada titik tertentu dalam eksekusi sistem. Berikut adalah sequence diagram pada sistem absensi berbasis QR Kode pada Kampus Polinas LP3I Alauddin Makassar :

1. Squence Diagram Kehadiran Mahasiswa

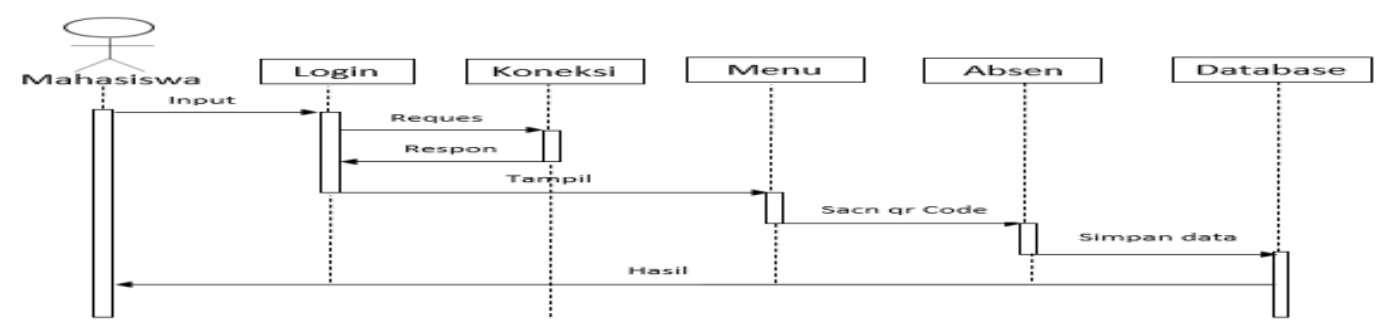

2. Squence Diagram Mahasiswa Request

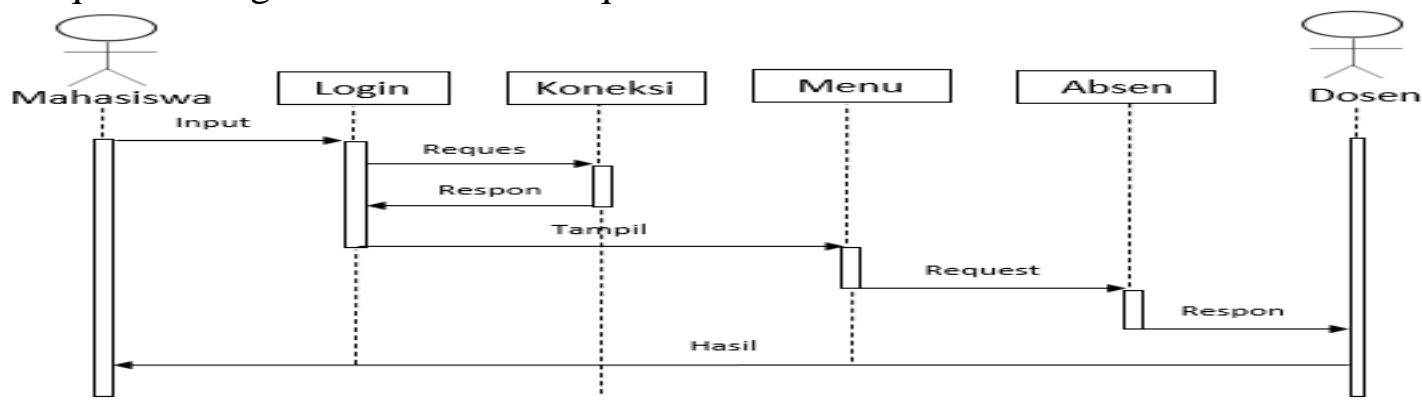

3. Squence Diagram Dosen 


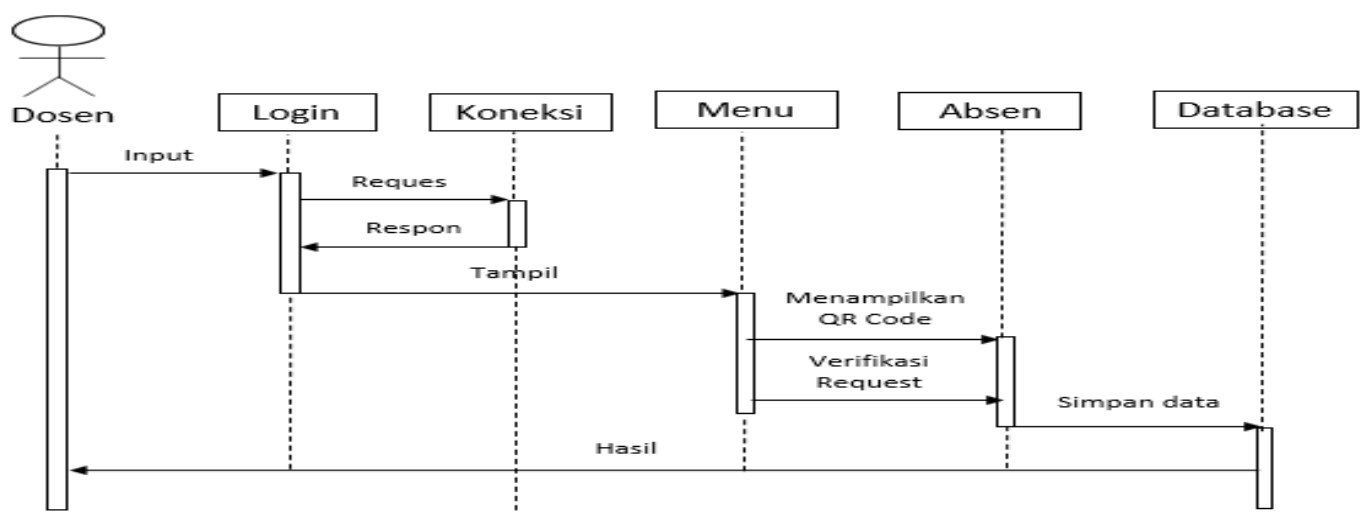

4. Squence Diagram Akademik

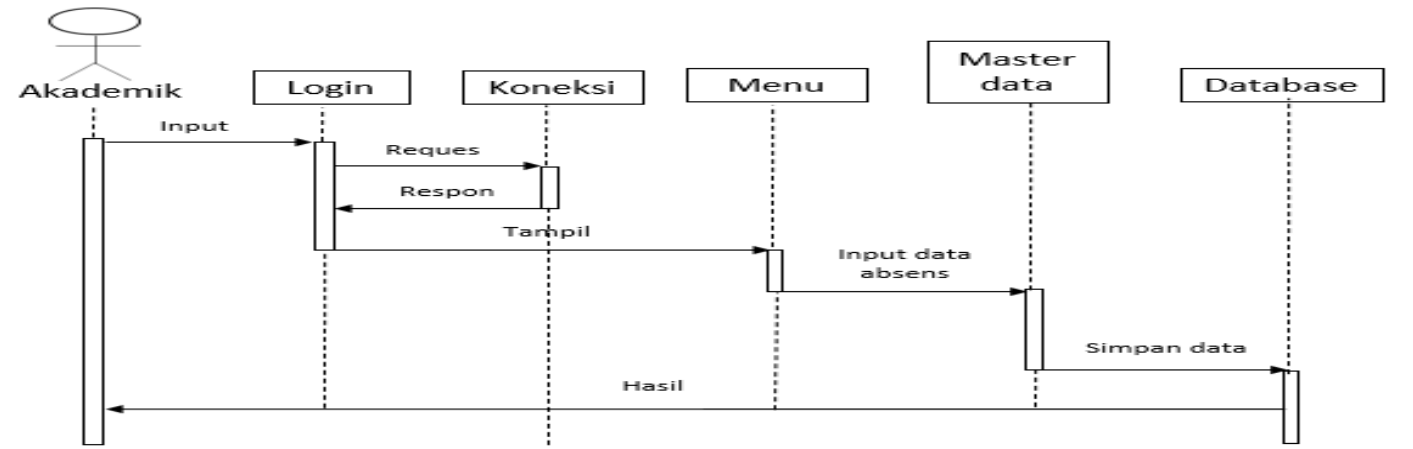

\section{Desain colaboration diagram}

Menggambarkan Interaksi antra object yang memiliki perang yang berbeda, colaboration diagram yang

1. Colaboration Diagram Mahsaswa Yang Hadir

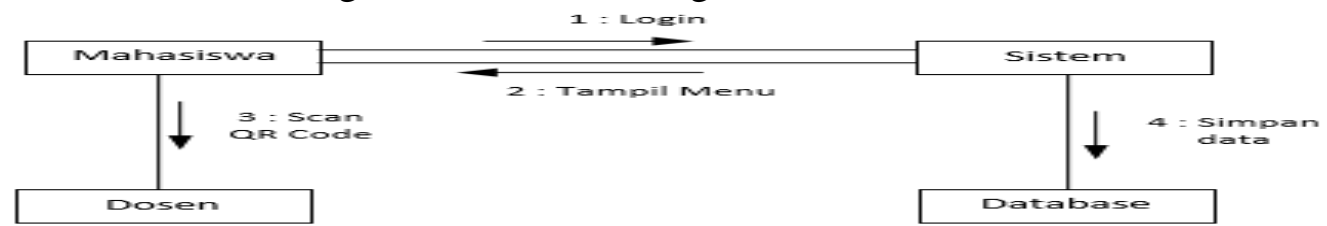

2. Colaboration Diagram Mahasiswa yang Request

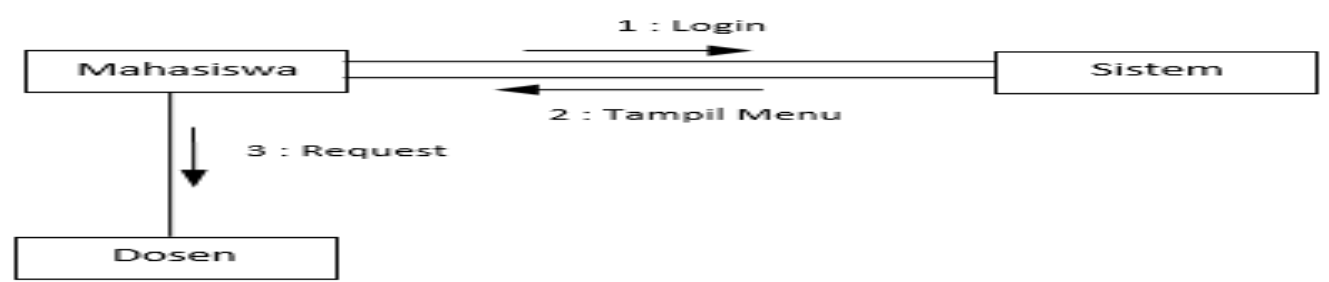

3. Calaboration Diagram Dosen 


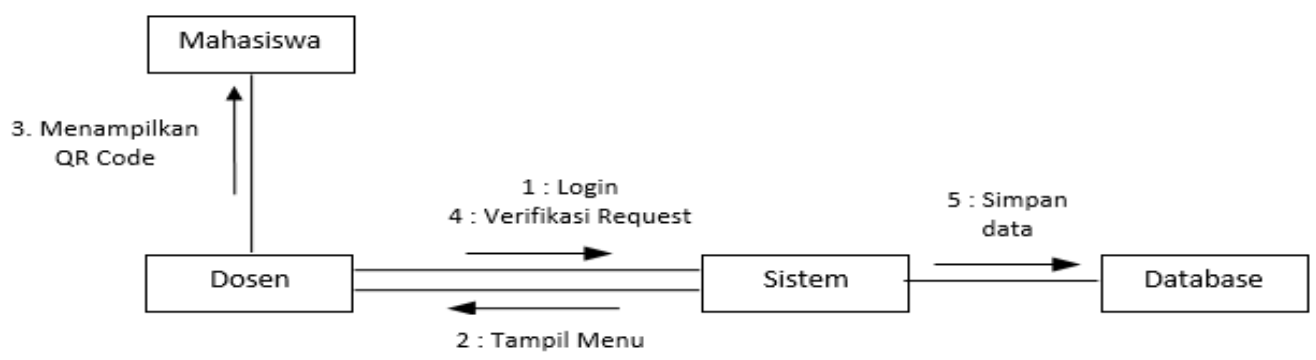

4. Colaboration Diagram Akademik

1 = Login

3 : Input data absensi

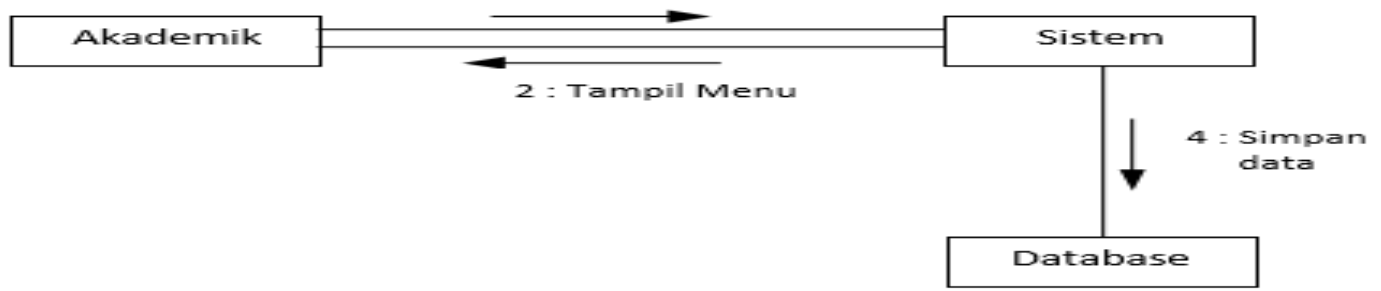

\section{Desain Activity Diagram}

Activity diagram adalah gambaran

Activity diagram diguanakan untuk yang medefinisikan aliran aktifitas menunjukkan aliran atau kejadian di yang berjalan pada suatu sistem. dalam sistem yang dirancang.

1. Activity Diagram Mahasiswa yang hadir

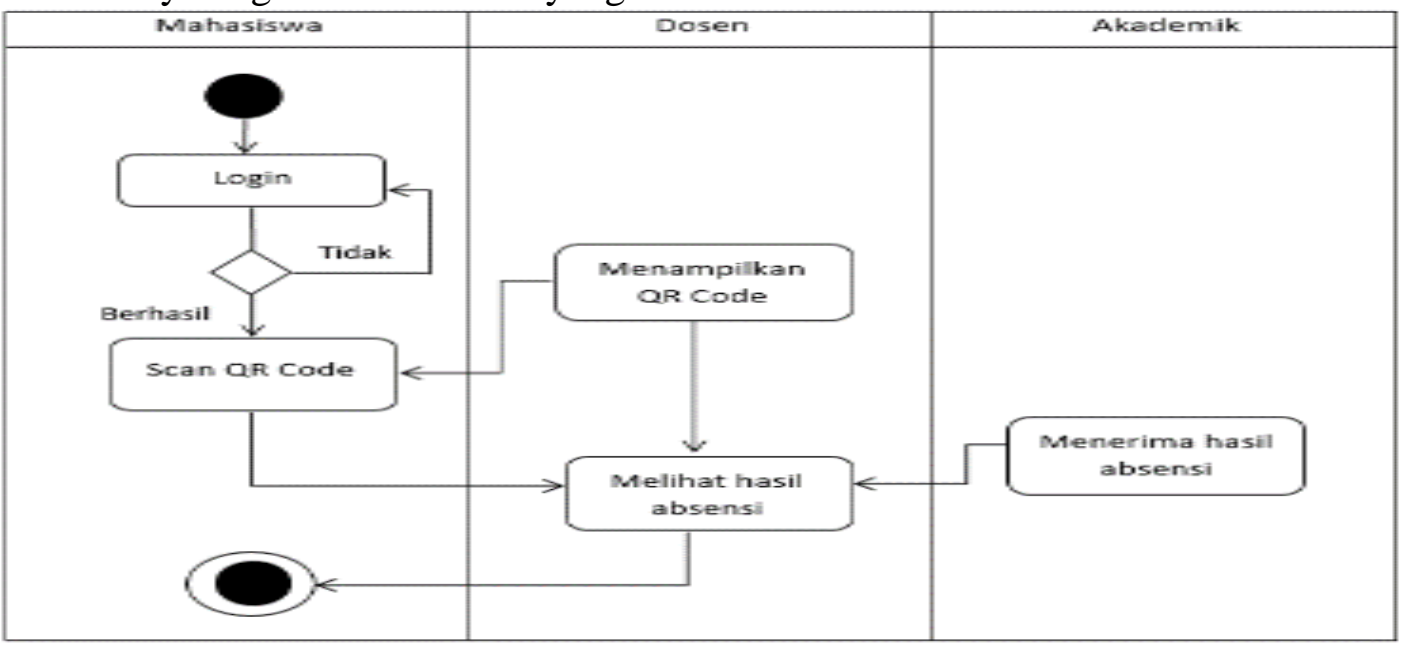

2. Activity Diagram mahasiswa yang request 


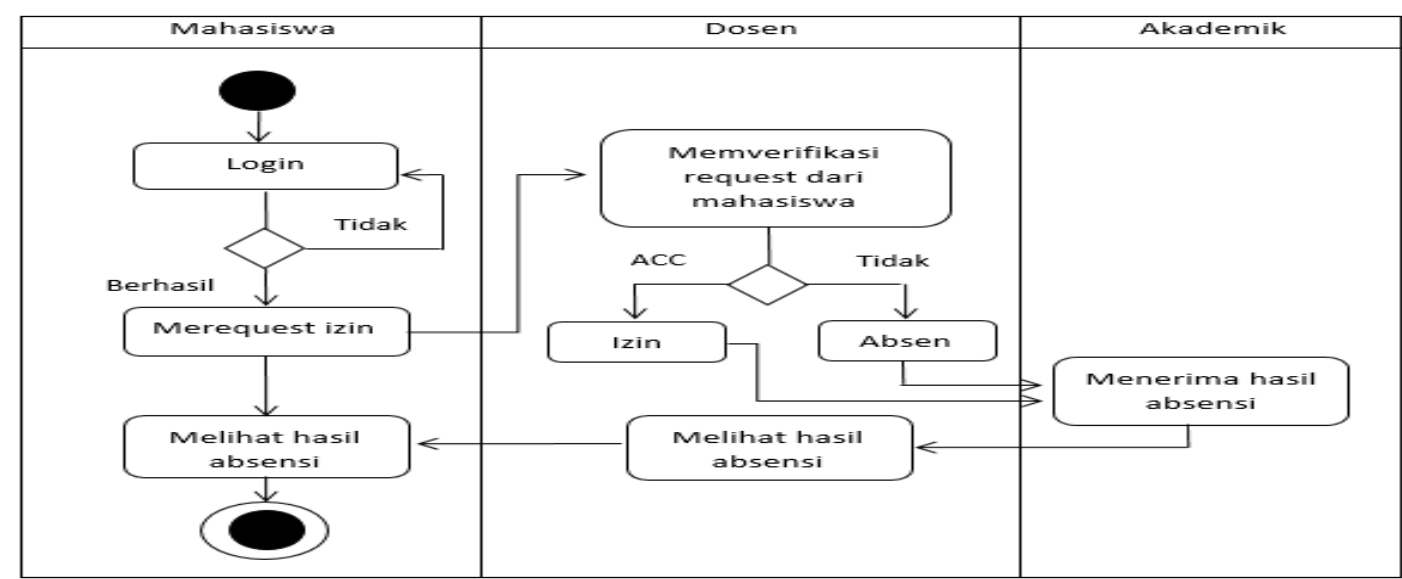

3. Activity Diagram Dosen

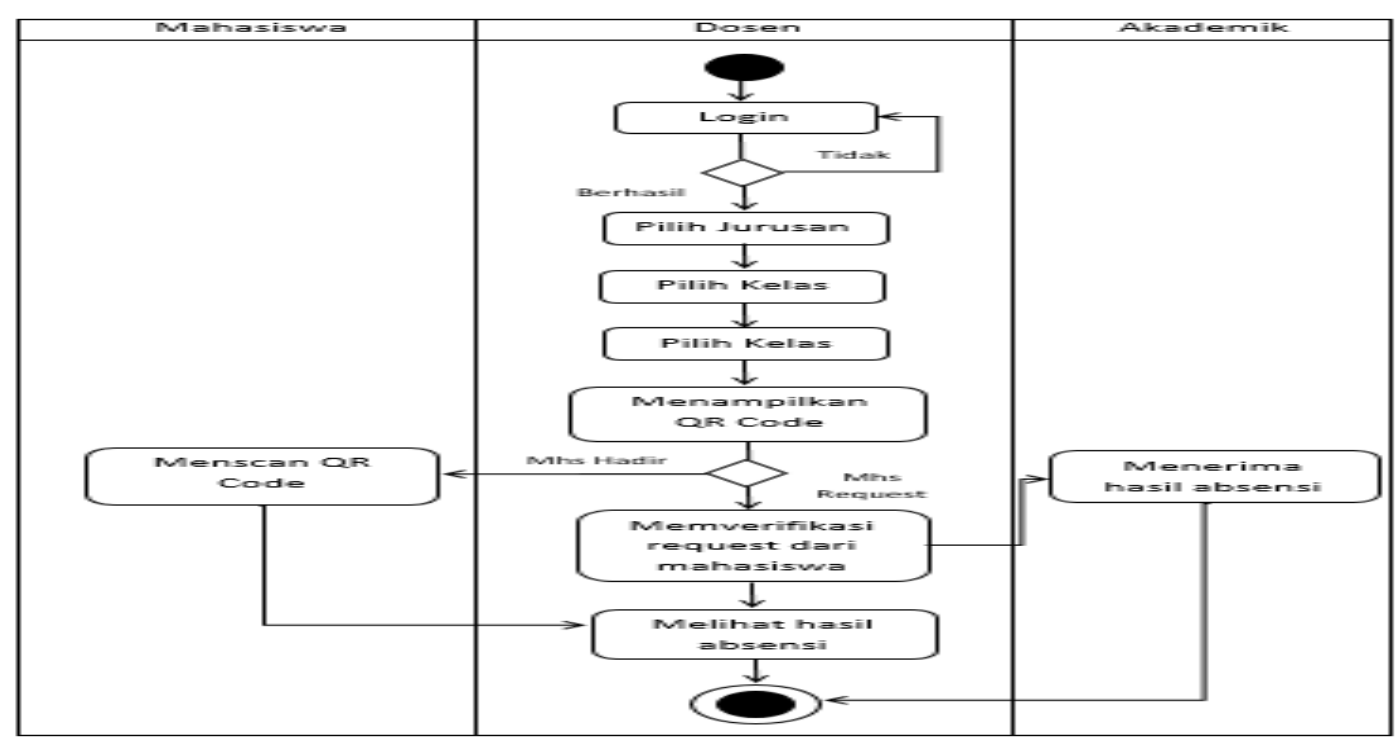

4. Activity Diagram Akdemik 


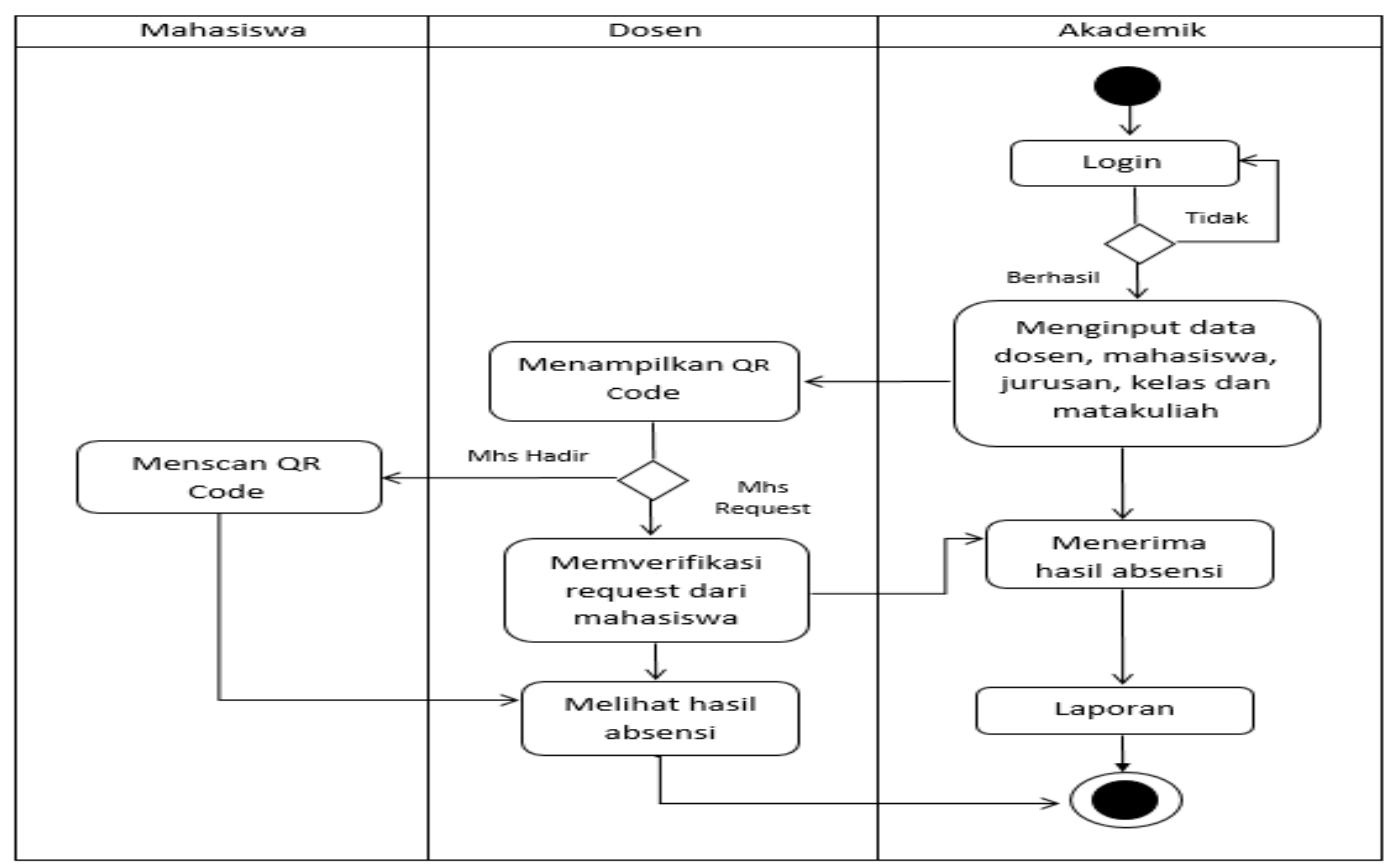

\section{Desain State Chart Diagram}

Statechart diagram merupakan penggabungkan semua state (kondisi) yang dimiliki dari suatu objek dari suatu class dan keadaan yang menyebabkan state berubah. Statechart diagram tidak digambarkan untuk semua class, hanya yang mempunyai sejumlah state yang terdefinisi dengan baik dan kondisi class berubah oleh state yang berbeda.

1. State Chart mahasiswa yang hadir

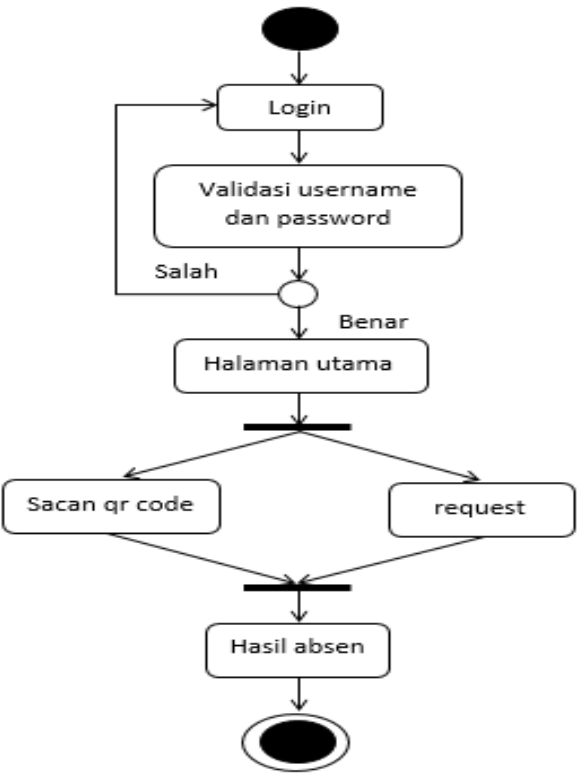

2. State Chart Dosen 


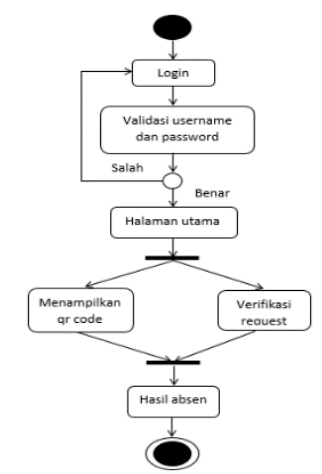

3. State Chart Akademik

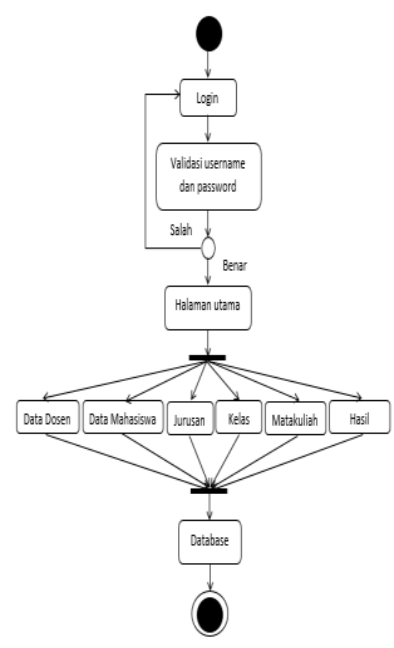

Componen Diagram

Package Diagram

Component adalah sebuah code module (kode-kode module). Diagram Component merupakan fisik sebenarnya dari diagram Class.

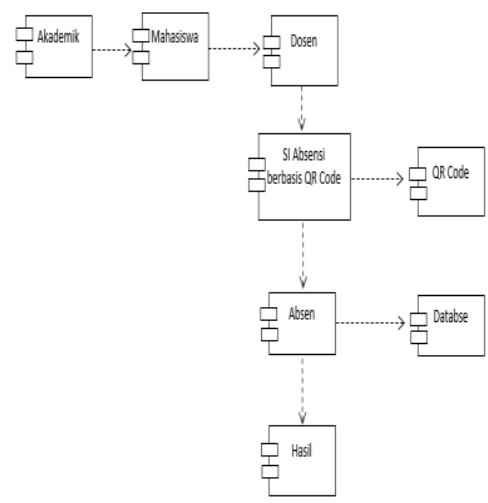

1. Develoyment Diagram

Development diagram adalah diagram yang digunakan memetakan software ke processing node. Menunjukkan konfigurasi elemen pemroses pada saat run time dan software yang ada di dalamnya. Diagram Ini adalah salah satu diagram paling penting dalam tingkat implementasi perangkat lunak.

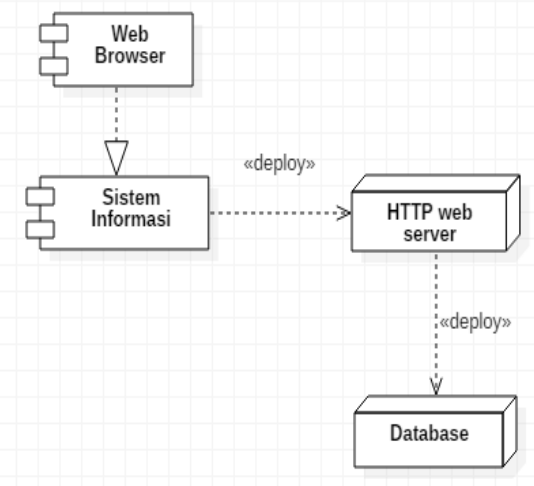

2. Desain Rancangan Basis Data

Perancangan sistem database menjelaskan tentang bagaimana rancangan-rancangan terhadap relasi antar tabel di dalam database sistem yang akan di usulkan dalam bentuk penjabaran diagram. Berikut adalah struktur dan relasi tabel yang akan di gunakan dalam perancangan sistem infomrasi absensi mahsiswa berbasis QR Pada kampus Polinas LP31 Alauddin Makassar..

a. Rancangan Secara Konseptual (Desain Logical)

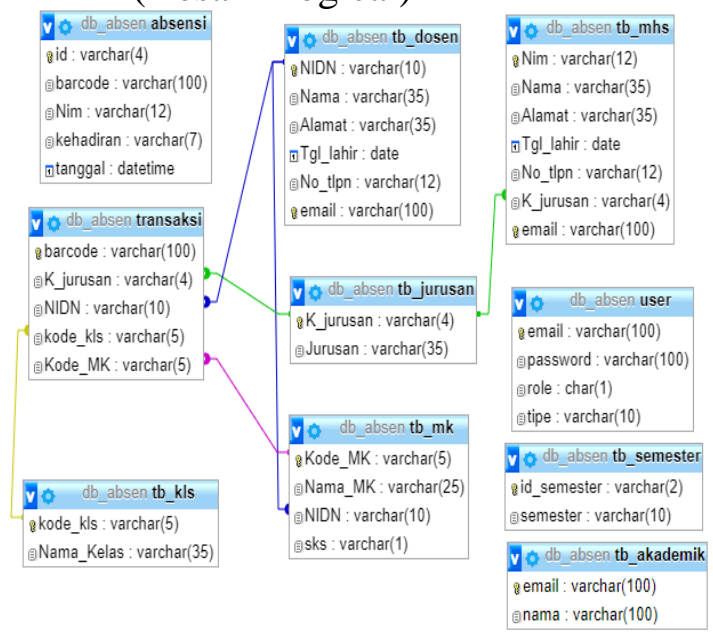

(C) 2020 STIE TDN. All rights reserved

Corresponding Author: 
Gambar 3.19 Rancangan Secara Konseptual (Logical Design

\section{Rancangan Struktur/Yang Terkandung Dalam sebuah File}

1. Rancangan tabel dosen

Nama File : Dosen

Media : Hard Disk

Isi : NIDN, Nama, Alamat, Tgl_lahir, No_tlpn,

Pasword

Primary Key : NIDN

Struktur : File tb_dosen

\begin{tabular}{|c|l|l|l|l|}
\hline No & Nama Field & Jenis & Lebar & Keterangan \\
\hline 1 & NIDN & varchar & 10 & Primary Key \\
\hline 2 & Nama & Varchar & 35 & - \\
\hline 3 & Alamat & Varchar & 35 & - \\
\hline 4 & Tgl_lahir & Date & - & - \\
\hline 5 & No_tlpn & Varchar & 12 & - \\
\hline 6 & password & varchar & 100 & - \\
\hline
\end{tabular}

2. Rancangan Tabel Mahasiswa

Nama file : Mahasiswa

Media : Hard Disk

Isi : NIM, Nama, Alamat, Tgl_lahir, No_tlpn,

K_jurusan, password

Primary key : NIM

Struktur : File tb_mhs

\begin{tabular}{|c|l|l|l|l|}
\hline No & \multicolumn{1}{|c|}{ Nama Field } & \multicolumn{1}{|c|}{ Jenis } & \multicolumn{1}{|c|}{ Lebar } & \multicolumn{1}{|c|}{ Keterangan } \\
\hline 1 & NIDN & varchar & 12 & Primary Key \\
\hline 2 & Nama & Varchar & 35 & - \\
\hline 3 & Alamat & Varchar & 35 & - \\
\hline 4 & Tgl_lahir & Date & - & - \\
\hline 5 & No_tlpn & Varchar & 12 & - \\
\hline 6 & K_jurusan & varchar & 4 & Foreign Key \\
\hline 7 & Password & varchar & 100 & - \\
\hline
\end{tabular}

3. Rancangan tabel jurusan

Nama file : Jurusan

Media : Hard Disk

Isi $\quad:$ K_jurusan, Jurusan

Primary key : K_jurusan

Struktur : File tb_jurusan

\begin{tabular}{|l|l|l|l|l|}
\hline No & Nama Field & Jenis & Lebar & Keterangan \\
\hline 1 & K_jurusan & varchar & 4 & Primary Key \\
\hline 2 & Jurusan & Varchar & 35 & - \\
\hline
\end{tabular}

Corresponding Author: 
4. Rancangan tabel kelas

Nama file : Kelas

Media : Hard Disk

Isi : kode_kls, Nama_Kelas

Primary key : kode_kls

Struktur : File tb_kls

\begin{tabular}{|l|l|l|l|l|}
\hline No & Nama Field & Jenis & Lebar & Keterangan \\
\hline 1 & Kode_kls & varchar & 5 & Primary Key \\
\hline 2 & Nama_Kelas & Varchar & 35 & - \\
\hline
\end{tabular}

5. Rancangan tabel matakuliah

Nama file : Matakuliah

Media : Hard Disk

Isi : Kode_MK, Nama_MK, NIDN,sks

Primary key : Kode_MK

Struktur : File tb_mk

\begin{tabular}{|l|l|l|l|l|}
\hline No & Nama Field & Jenis & Lebar & Keterangan \\
\hline 1 & Kode_MK & Varchar & 5 & Primary Key \\
\hline 2 & Nama_MK & Varchar & 35 & - \\
\hline 3 & NIDN & Varchar & 10 & Foreign Key \\
\hline 4 & sks & varchar & 2 & - \\
\hline
\end{tabular}

6. Rancangan tabel absensi

Nama file : Absen

Media : Hard Disk

Isi : id, barcode, NIM, kehadiran, tanggal

Primary key : id

Struktur : File absensi

\begin{tabular}{|l|l|l|l|l|}
\hline No & Nama Field & Jenis & Lebar & Keterangan \\
\hline 1 & Id & Varchar & 4 & Primary Key \\
\hline 2 & barcode & Varchar & 100 & - \\
\hline 3 & NIM & Varchar & 10 & Foreign Key \\
\hline 4 & kehadiran & Varchar & 7 & - \\
\hline 5 & tanggal & datetime & - & - \\
\hline
\end{tabular}

7. Rancangan tabel absensi

Nama file : Transaksi

Media : Hard Disk

Isi : barcode, K_jurusan, Nama_MK, NIDN,

Nama_Kelas

Primary key : barcode

Struktur : File transaksi

\begin{tabular}{|l|l|l|l|l|}
\hline No & Nama Field & Jenis & Lebar & Keterangan \\
\hline 1 & barcode & Varchar & 100 & Primary Key \\
\hline
\end{tabular}

Corresponding Author:

(C) 2020 STIE TDN. All rights reserved 


\begin{tabular}{|l|l|l|l|l|}
\hline 2 & K_jurusan & & 4 & Foreign Key \\
\hline 3 & Nama_MK & Varchar & 25 & Foreign Key \\
\hline 4 & NIDN & Varchar & 10 & Foreign Key \\
\hline 5 & Nama_Kelas & Varchar & 35 & - \\
\hline
\end{tabular}

8. Rancangan tabel akademik

Nama file : Akademik

Media : Hard Disk

Isi : email, nama

Primary key : email

Struktur : File tb_akademik

\begin{tabular}{|l|l|l|l|l|}
\hline No & Nama Field & Jenis & Lebar & Keterangan \\
\hline 1 & email & Varchar & 100 & Primary Key \\
\hline 2 & Nama & Varchar & 100 & - \\
\hline
\end{tabular}

9. Rancangan tabel semester

Nama file : Semester

Media : Hard Disk

Isi : id_semester, semester

Primary key : email

Struktur : File tb_semester

\begin{tabular}{|l|l|l|l|l|}
\hline No & Nama Field & Jenis & Lebar & Keterangan \\
\hline 1 & Id_semester & Varchar & 2 & Primary Key \\
\hline 2 & semester & Varchar & 10 & - \\
\hline
\end{tabular}

10. Rancangan tabel user

Nama file : User

Media : Hard Disk

Isi : email,password, role

Primary key : email

\begin{tabular}{|l|l|l|l|l|}
\hline No & Nama Field & Jenis & Lebar & Keterangan \\
\hline 1 & email & Varchar & 100 & Primary Key \\
\hline 2 & password & Varchar & 100 & - \\
\hline 3 & role & & 1 & \\
\hline
\end{tabular}

\section{Rancangan Kebutuhan Teknologi}

\section{Spesifikasi Hardware}

Perangkat keras atau hardware adalah suatu alat bantu yang berbentuk fisik atau seluruh komponen peralatan yang membentuk suatu sistem komputer dan peralatan lainnya yang memungkinkan komputer dapat melaksanakan tugasnya. Adapun perangkat keras yang digunakan dalam sistem usulan adalah sebagai berikut:

a. Processor : Intel(R) Pentium(R) CPU $987 @ 1.50 \mathrm{GHz} 1.50 \mathrm{GHz}$

b. Kapasitas Memory : DDR 2 GB

c. Kapasitas hardisk : 500 GB

d. Mouse + Keyboard

(C) 2020 STIE TDN. All rights reserved

Corresponding Author: 
2. Spesifikasi Softwere

Adapun perangkat lunak yang digunakan dalam sistem usulan adalah sebagai berikut :

a. Sistem Operasi : Windows 10

Pro

b. Server localhost : XAMPP 3.2.2

\section{HASIL DAN PEMBAHASAN}

\section{Implementasi dan Pengujian Sistem}

1. Penerapan Sistem Informasi absensi mahasiswa berbasis QR Pada

Kampus Polinas Sultan Alawuddin Makassar .

a. Form Halaman Login Dosen

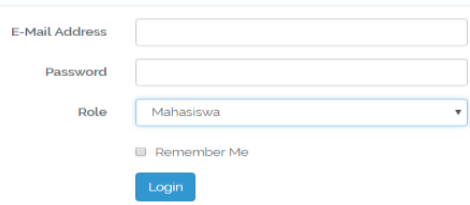

Setiap pengguna yang ingin masuk kedalam sistem, harus terlebih dahulu mengakses web dan melakukan login sesuai dengan username dan password masing-masing pengguna

b. Form Halaman Awal Dosen

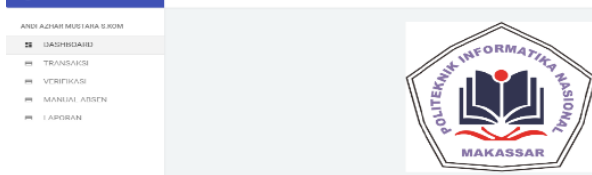

Setelah melakukan login, dan data yang dimasukkan benar, maka sistem akan menampilkan halaman utama mahasiswa, serta menu yang ada pada sistem seperti gambar di atas

c. Form Halaman Proses Transaksi absensi

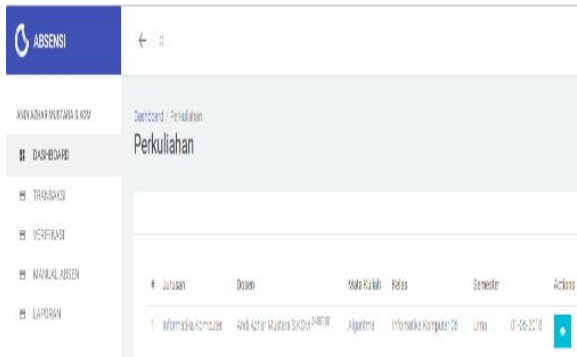

Dalam halaman ini berisi data matakuliah setiap code

d. Form Halaman QR CODE

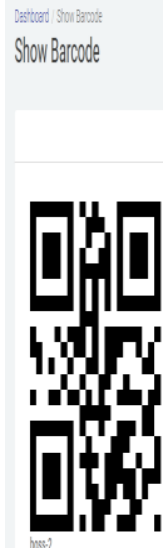

Dalam halaman ini dosen menampilkan QR Code untuk mengabsen Mahasiswa

e. Form Halaman Request Absensi Reovest Ahosens

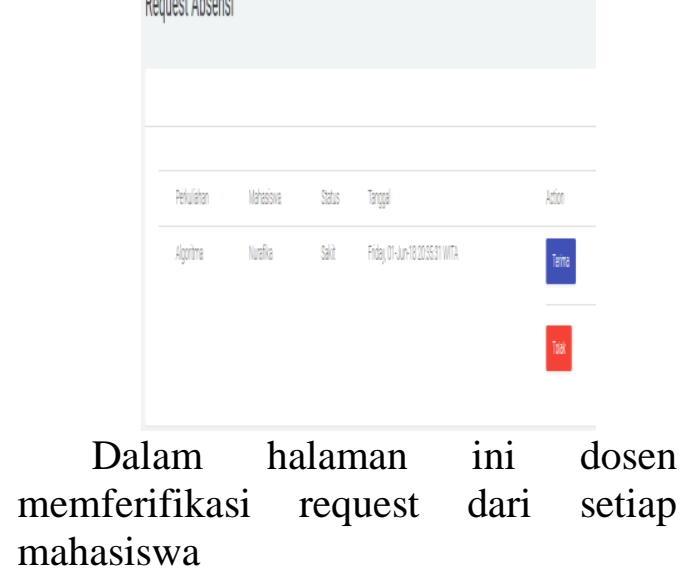




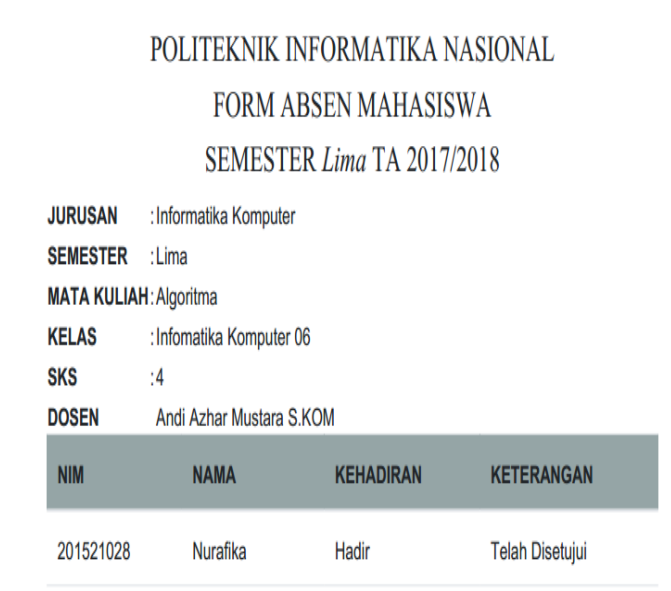

f. Form Halaman Manual absensi

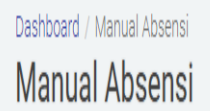

Dalam halaman ini dosen dapat mengabsen manual mahasiswa yang tidak membawa atau memiliki handphone jika absen manual berhasil maka dalam halaman ini akan muncul keterangan ketika dosen berhasil mengabsen manual mahasiswa

\section{g. Form Halaman Pilih Laporan}

Pada halaman ini berisiskan pilihan laporan Permatakuliah

\section{POLITEKNIK INFORMATIKA NASIONAL \\ FORM ABSEN MAHASISWA \\ SEMESTER Lima TA 2017/2018}

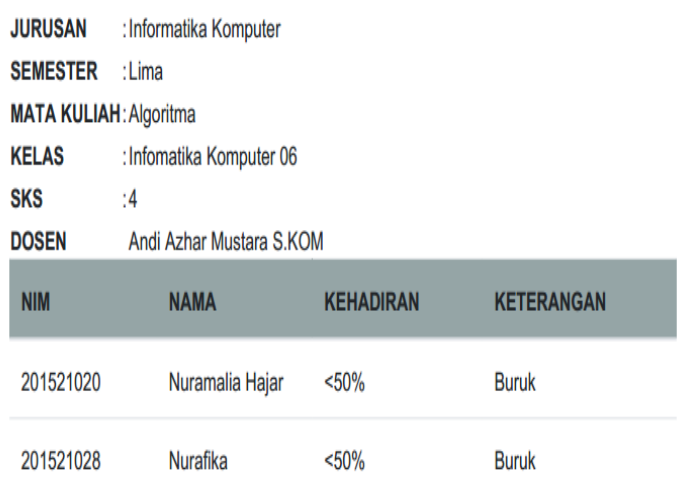

Dalam halaman ini dosen dapat melihat hasil absensi mahasiswa di setiap pertengahan san akhir semester

\section{KESIMPULAN DAN SARAN}

\section{Kesimpulan}

1. Perancangan sistem absensi kelas berbasis QR Code menggunakan PHP \& MySql pada kampus POLINAS LP3I Alauddin Makasar" yang dapat diterapkan dalam sebuah web server online mupun dalam localhost untuk diakses menggunakan browser.

2. Sistem ini dapat menunjang terselenggaranya sistem manajemen berbasis IT pada kampus POLINAS LP3I Alauddin Makassar untuk kegiatan absensi. Dengan terselesaikannya sistem ini diharapkan dapat mengefisenkan waktu dalam kegiatan mengabsen dan mencegah terjadinya manipulasi absen serta dapat membantu pihak akademik mendata kehadiran mahasiswa dengan mudah dan efisien. maka pada pengembangan selanjutnya diharapkan dapat dikembangkan oleh SDM lainnya 
untuk memenuhi kebutuhan dimasa yang akan datang serta dapat digabungkan dengan program aplikasi lainnya, sehingga cakupan kegunaannya menjadi lebih luas dan lebih lengkap.

3. Serta perlunya kombinasi antara sistem yang telah berjalan, maka penulis menyarankan kepada semua pihak yang agar optimalisasi sistem absensi berbasis QR Code ini dapat dikombinasikan antara sistem yang telah berjalan.

\section{Saran}

1. Dalam rancagan system informasi absensin saya menyadari masih terdapat banyak kekurangan yang dapat diperbaiki maupun dilengkapi karena dalam pembuatan perangkat lunak ini, masih jauh dari kata sempurna serta adanya keterbatasan waktu,

\section{DAFTAR PUSTAKA}

Nugroho,Adi 2009'Rekayasa

Perangkat Lunak Menggunakan UML Dan JAVA Penerbit Andi Yogyakarta

Nugroho, Adi.2014. Analisis dan Desain Sistem Informasi. Yogyakarta: Andi.

Muhammad Irfan, gusnasari (2017) 'Pembelajaran dan simulasi bahasa inggris berbasis android pada forum kampung bahasa sulawesi (fkbs.
Edhy Sutanta,2011 "Basis Data Dalam Tinjauan Konseptual"Penerbit CV,Andi Offset Yogyakarta.

Indra Griha Topik Isa, George Pri Hartawan. 2017. Perancangan aplikasi koperasi simpan pinjam berbasis web (studi kasus koperasi mitra setia).

Sri Mulyani, Ak., CA. 2016. Metode Analisis dan Perancangan Sistem.

Ilka. Zulfria. 2015. Pemodelan berbasi UML ( Unified Modeling Language ) dengan Strategi Teknik Orientasi Objek User Centered Design ( UCD ) dalam Sistem

Administrasi Pendidikan Ilka Zufria Fak Sains \& Teknologi UIN Sumatera Utara Medan Abstrak

Kusnedi. 1999. Konsep Dasar Informasi

AgungSr. 2011. Sistem Informasi

Google.com
Rosa,A.S 2015 Bandung"Rekayasa Perangkat Lunak"Penerbit Informatika Bandung

Wikipedia.co.id 